\title{
Perception of Palm Oil Clusters Development in Cameroon
}

\author{
${ }^{1}$ Belinga Thierry, ${ }^{2}$ Zhou Jun, ${ }^{3}$ Wei Long, ${ }^{4}$ Gahe Zimy Samuel Yannick, ${ }^{5}$ Ngomah Le Temps \\ 1, 2, 3, 4, 5 Wuhan University of Technology, School of Economics, 122 Luoshi Road, Wuhan, China
}

\begin{abstract}
2017 Research Leap/Inovatus Services Ltd. All rights reserved.

DOI: $10.18775 /$ jibrm.1849-8558.2015.23.3005 URL: http://dx.doi.org/10.18775/jibrm.18498558.2015.23.3005

\section{Keywords: \\ Clusters; \\ Palm oil clusters; \\ Regression.}

The aim of this research paper is to find the factors that influence the development of palm oil clusters in Cameroon using a survey made among 296 individuals. From the regression model, we find that palm oil production, agribusiness schools, market development, palm wine production and clusters development by area have a negative and significant impact on palm oil clusters development in Cameroon, implying that the government and financial institutions have to do more in order to have the palm oil clusters well developed in Cameroon.
\end{abstract}

\section{Introduction}

The research carries out on this paper brings forth insights on the palm oil cluster development in Cameroon. Since the development of business clusters by Porter and Krugman this strategy has become the focus of many regions in the world and Africa as well (Porter, 2000 and Krugman, 1991). Undertaking this research on palm oil clusters in Cameroon seems crucial as we know how important is the contribution of agriculture in the overall economic growth of most African countries in general and Cameroon in particular. To reach our goal we have undertaken a survey among 296 Cameroonians living abroad and in the homeland.

This study contributes to the literature on agribusiness clusters development in Africa. Firstly, in our development we will present a brief overview of agro-based clusters in Africa and in Cameroon. Secondly, we will run our model using 14 key questions that will enable us to capture the perception of palm oil clusters development in Cameroon, those questions are designed using the palm oil industry cluster network in Cameroon. Thirdly, the outcomes of the regression model will help us to draw important conclusions for policy-makers.

\section{Agro-based clusters in Africa}

The first scholars to analyze clusters development in Africa are McCormick, and Mitullah, who started collecting material on clusters and investigated whether the benefits that clustering provided in other parts of the world could also be applied in Africa. From the literature, we find that African clusters is depending on internal structure and level of industrialization. Three types of clusters can be observed in Africa. The first category is the groundwork cluster that provides a basis for development by improving producers' access to markets. The second cluster is the industrializing cluster that started the process of specialization and differentiation. The third type is the complex cluster that has already diversified its size structure and linkages and is able to tap wider national or international markets (Mc Cormick, 1998 and Mitullah, 1999). Groundwork clusters are more common in Africa, followed by industrializing clusters, whereas only a few complex clusters are found (Mc Cormick, 1998, 1999).

The World Bank Institute started some work on African clusters with its initiative called Knowledge, Technology and Growth in Africa in 200506 (Zeng,2008). The initiative delivered 11 case studies, 3 of which are in the agricultural sector: fish clusters in Uganda, a Kenyan cut flower cluster and a South African wine cluster. The general conclusions were that African clusters face enormous challenges, and that their sustainability depends on how successfully they can overcome them. Resource-based clusters, especially those in the agricultural sector, need to find solutions to avoid resource depletion and to upgrade their products. Most importantly, the public sector needs both to establish a favorable regulatory and incentive environment, facilitating knowledge and technology learning and innovation, and to provide high-quality public goods, notably infrastructure, that the private sector can benefit from (Zeng, 2008).

\section{Palm oil cluster development in Cameroon}

Industrial production of palm oil is not new to Cameroon. The first commercial plantations were established in 1907 under the German colonial administration in the coastal plains, around Mt. Cameroon and Edea. The crop was further developed under the Franco-British regime until 1960 when it had reached an estimated production of 42,500 tons. After Independence, the government of Cameroon took over the production of palm oil with the creation of public sector companies like Société des Palmeraies. According to the Ministry of Agriculture and Rural Development, Cameroon produced 230,000 tons of crude palm oil 
in 2010, across an estate of approximately 190,000 hectares (Hoyle and Levang, 2012).

The Government of Cameroon's Rural Sector Development Plan proposes an increase in palm oil production to 300,000 tons in 2015 and 450,000 tons in 2020 . This can be achieved primarily through increasing oil production yields, as well as potentially increasing the area under oil palm production and by increasing oil extraction rates.

The Government's plan is focused mainly on the area under production targets and not on yields or any environmental or biodiversity impacts.

The expected results of the Palm Oil Cluster in Cameroonians order to apprehend the expected impact of Palm Oil Cluster in Cameroon, we should have a look first of on the different derivatives of Palm Oil. From the total production of total Palm Oil in Cameroon: $80 \%$ are used for food such as: margarine, vegetable fat base, cooking oil, frying oil and specialized fats; $20 \%$ are used for: The manufacture of industrial uses derivatives: fatty acids, soaps and cosmetics, industrial soaps, inks, resins, methyl esters, animal feed. Besides the fruit, other parts are frequently used in Cameroon including the fermented sap that is used for palm wine $\&$ liquor, bioenergy produced by the fibers, the trunk for woodworking, the fins or leaves are used as roofs (Hoyle and Levang, 2012).

Some other connected industries are attached to palm oil production such as transportations, mechanic enterprises, cosmetic enterprises (lotion, soap, etc.), banks and microfinance, fertilizers companies, specialized education center in Palm Oil production, agro-food industries, local Associations of farmers and non-government organizations (Figure 1).

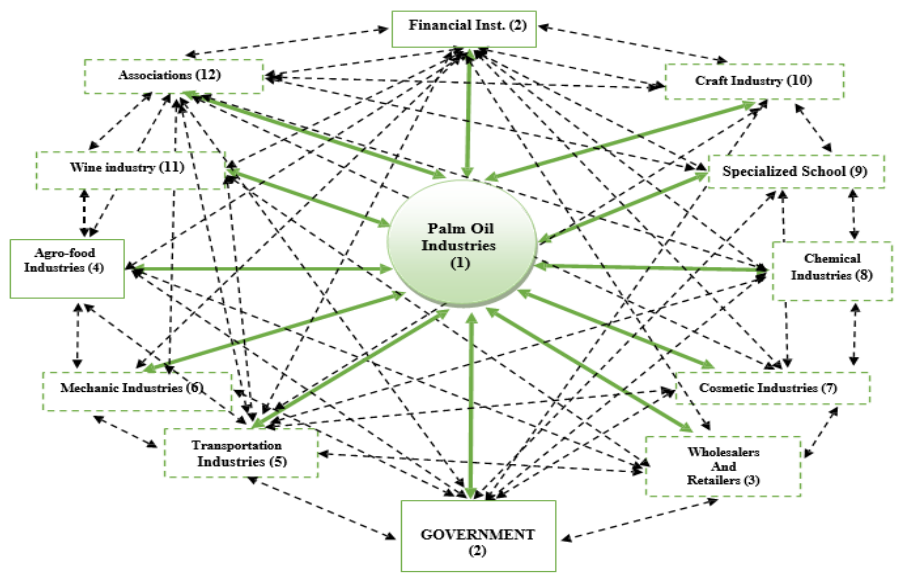

Figure 1: Palm Oil Industry Cluster Network in Cameroon Source: Source: Author based on observations made on the field

Figure 1 shows all the multi -interconnexions of the Palm-Oil Cluster in Cameroon. The intended Cluster designed by the government in $1960 \mathrm{~s}$ had initially, the purpose to bring forth a great development in all the regions were the Palm Oil Companies were established.

\section{Empirical Analysis \\ 4.1 Methodology}

To undertake this research on the perception of palm oil cluster development in Cameroon we have designed a questionnaire made up of two groups of questions:

The first group of questions deal with the identity of the interviewee. In that category people were asked to give details on their place of residence and occupation. The second group of questions was made up of 13 questions directly related to the palm oil cluster development.

Q3: Perception on the Palm Oil Production in the various Clusters.

Q4: Assessment of the Government and Financial Institutions involvement on the Palm Oil Clusters development.

Q5: Perception on the development of Wholesalers and Retailers in the Palm Oil Clusters.

Q6: Perception on the Agro food development in the Palm Oil Clusters.

Q7: Perception on the Cosmetic Business development in the Palm Oil Clusters.

Q8: Perception on the Agrochemical Industry development in the Palm Oil Clusters.

Q9: Assessment of the Agribusiness Transportation development in the Palm Oil Clusters.

Q10: Presence of Agri-schools in the Palm Oil Clusters of Cameroon.

Q11: Perception of the Craft Industry development in the Palm Oil Clusters.

Q12: Assessment of the Palm Wine business development in the Palm Oil Clusters.

Q13: Perception on the Performance of the Agro-organizations and NGO in the Palm Oil Clusters.

Q14: Perception on the overall Palm Oil Clusters development in various areas.

Q15: Perception on the Palm Oil Cluster development in Cameroon.

Table 1: Regression Model Outcomes

\begin{tabular}{|c|c|c|c|c|}
\hline \multicolumn{5}{|c|}{ Dependent Variable: Q15 } \\
\hline \multicolumn{5}{|c|}{ Method: Least Squares } \\
\hline \multicolumn{5}{|c|}{ Date: $11 / 25 / 16$ Time: 00:27 } \\
\hline Variable & Coefficient & Std. Error & t-Statistic & Prob. \\
\hline $\mathrm{C}$ & 0.038031 & 0.036003 & 1.056331 & 0.2967 \\
\hline Q3 & -0.838139 & 0.272727 & -3.073181 & 0.0037 \\
\hline Q4 & 1.675604 & 0.478244 & 3.503659 & 0.0011 \\
\hline Q5 & -1.405968 & 0.395528 & -3.554665 & 0.0009 \\
\hline Q6 & 0.223804 & 0.109519 & 2.043514 & 0.0472 \\
\hline Q7 & 0.288159 & 0.133705 & 2.155180 & 0.0368 \\
\hline Q8 & 0.876986 & 0.354918 & 2.470956 & 0.0175 \\
\hline Q9 & -0.314440 & 0.171610 & -1.832296 & 0.0738 \\
\hline Q10 & -1.759949 & 0.383777 & -4.585866 & 0.0000 \\
\hline Q11 & 2.033344 & 0.377728 & 5.383092 & 0.0000 \\
\hline Q12 & -0.494377 & 0.198902 & -2.485529 & 0.0169 \\
\hline Q13 & 2.551080 & 0.617127 & 4.133801 & 0.0002 \\
\hline Q14 & -0.708991 & 0.263469 & -2.690979 & 0.0101 \\
\hline R-squared & 0.763860 & \multicolumn{2}{|c|}{$\begin{array}{l}\text { Mean dependent } \\
\text { var }\end{array}$} & 0.196429 \\
\hline $\begin{array}{l}\begin{array}{l}\text { Adjusted R- } \\
\text { squared }\end{array} \\
\end{array}$ & 0.697960 & \multicolumn{2}{|c|}{ S.D. dependent var } & 0.400892 \\
\hline S.E. of regression & 0.220323 & \multicolumn{2}{|c|}{$\begin{array}{l}\text { Akaike info } \\
\text { criterion }\end{array}$} & 0.012687 \\
\hline Sum squared resid & 2.087309 & \multicolumn{2}{|c|}{ Schwarz criterion } & 0.482858 \\
\hline Log likelihood & 12.64477 & \multicolumn{2}{|c|}{$\begin{array}{l}\text { Hannan-Quinn } \\
\text { criter. }\end{array}$} & 0.194971 \\
\hline F-statistic & 11.59128 & \multicolumn{2}{|c|}{ Durbin-Watson stat } & 2.295003 \\
\hline Prob(F-statistic) & 0.000000 & \\
\hline
\end{tabular}

Source: Author using primary data on Eviews. 
We have designed an online survey, meaning that all the people who undertook the survey had to meet the minimum requirement of having an internet Connexion.

Our empirical analysis consists of an econometric analysis using the Index $\mathrm{Q}_{15}$ as the sum of all the perception of Development of Cluster's Sectors. Input using coefficient $\beta_{\mathrm{i}}$ using Eviews. Literally this is the Index that we are going to compute:

$$
Q_{15}=\beta_{0}+\sum_{i=3}^{14} \beta_{i} Q_{i}
$$

\subsection{Findings}

The outcomes of this research show we have indexes with a negative and positive impact on the palm oil clusters development in Cameroon.

From the table 1, at 5\% significance level, the results show that the following parameters: Palm Oil production (Q3, $\beta 3$ : -0.83813), the market development represented by wholesalers and retailers $(\mathrm{Q} 5, \beta 5$ : 1.40596), agribusiness schools development (Q10, $\beta 10:-1.75994)$, the palm wine development (Q12, $\beta 12:-0.49437)$, the palm oil cluster development by area (Q14, $\beta 14$ : -0.70899) have negative and significant impact on the palm oil clusters development in Cameroon. The development of transportation (Q9, $\beta 9$ : - 0.31443$)$ is also negatively influencing the development of the clusters but has a significant impact only at $10 \%$ level of significance.

The results of the regression model also shows that 5\% significance level, the Government and Financial Institutions involvement on the Palm Oil Clusters development (Q4, $\beta 4: 1.67560)$, the Agro food development in the Palm Oil Clusters (Q6, $\beta 6$ : 0.22380), Cosmetic Business development $(\mathrm{Q} 7, \beta 7$ : 0.28815), the agrochemical industry development $\quad(\mathrm{Q} 8, \beta 8$ : 0.87698 ), Craft Industry development and the performance of the agroorganizations and NGO have a positive and significant impact on the overall palm oil development in Cameroon (Table 1), this finding implies that a strong involvement of the Cameroonian government and financial institution to develop the palm oil clusters in Cameroon.

\section{Conclusion and Recommendations}

The development of palm oil clusters in Cameroon is negatively and significantly impacted by key parameters such as: palm oil production, market development, development of agribusiness education, palm wine development, transportation development and palm oil development in each area. Even though the results show a strong involvement of the Government and the financial institutions to improve the clusters development, a lot remains to do. This implies that the palm oil technology used needs to be improved, the human resources knowledge to be updated and more qualified personnel to be hired in order to increase the level of production. As the level of technology is directly connected to finance, this finding also implies that even though we have a positive and significant impact of financial institution involvement on palm oil clusters development in Cameroon, we still need more finance to reach the optimum level of production in the palm oil industry of Cameroon.

The negative and significant impact of transportation development on the overall palm oil clusters development in Cameroon shows that investing in infrastructure like roads to connect business to business and people to businesses will definitely improve the cluster's development. This investment should also include the design of appropriate vehicle that will enable the farmers to bring their products to the various market places. Beside the development of infrastructure such as roads, it is very important to invest in innovative ideas to design and promote palm oil related products such as palm wine that is still underdeveloped in Cameroon. So, establishing research and development organizations on palm oil products will definitely bring forth positive impact on the overall palm oil clusters development in Cameroon.

\section{References}

- Porter, M. (2000), Location, Competition, and Economic Development: Local Clusters in a Global Economy. Economic Development Quarterly, 14 (1): 15-34, CrossRef

- Krugman P., (1991) Geography and Trade. MIT Press.

- $\quad$ McCormick, D., (1998). Enterprise Cluster in Africa: On the way to Industrialization? IDS Discussion paper 366, Institute of Development Studies, Sussex, UK.

- McCormick, D., (1999). African enterprise clusters and industrialization: theory and reality. World Development, 27(9): 1531-1551, CrossRef

- McCormick, D., (2003). Can Africa Industrialize Through Enterprise Clusters? The Courier, 196,

- $\quad$ pp. 33-35.

- Hoyle, D. \& Levang, P. (2012). Oil Palm Development in Cameroon. An adhoc working paper. WWF, Institut de Recherche pour le développement, CIFOR.

- Mitullah, W., (1999). Lake Victoria's Nile perch fish cluster: institutions, politics and joint action. IDS Working Paper 87 Institute of Development Studies, Sussex, UK.

- Zeng D. (2008). Knowledge, technology and cluster-based growth in Africa. WBI Learning Resources Series. The International Bank for Reconstruction and Development and the World Bank, Washington, D.C, $\underline{\text { CrossRef }}$ 